\title{
PEDAAGOGY
}

\section{Developing the Readiness of Correctional Officers to Act in Emergency Situations in the Context of Implementation of the Competence-Based Approach in Educational Process}

\author{
ELENA S. LOBANOVA \\ Vologda Institute of Law and Economics of FSIN Russia, Vologda, Russian \\ Federation \\ ORCID: https://orcid.org/0000-0002-8957-7417, e-mail: alenushka-248@yandex.ru
}

\section{TAT'YANA V. KIRILLOVA}

Research Institute of FSIN Russia, Moscow, Russian Federation

ORCID: https://orcid.org/0000-0001-8394-897X, e-mail: tatiana-kirillova@ rambler.ru

\section{VASILIIV. SMYKOVSKII}

Directorate of FSIN Russia in the Arkhangelsk Oblast, Arkhangelsk, Russian Federation

ORCID: https://orcid.org/0000-0001-9503-2897, e-mail: vvs-80@mail.ru

\section{Abstract}

Introduction: the article analyzes possibilities and topical issues of developing the readiness of correctional officers to act in emergency situations in educational process in educational institutions, taking into account requirements of the competence-based approach. Aim: to identify problems and ways to address them in the framework of developing cadets' readiness to act in emergency situations in penal institutions; the aim is achieved with the help of the following means: generalization of pedagogical experience in the application of the competence-based approach in education and the requirements of professional activity of penitentiary system staff; and analysis of the content of educational programs and programs of academic disciplines. Methods: theoretical analysis of the research problem, theoretical methods of formal and dialectical logic, analysis of documents and statistical data, survey, interpretation. Results: analysis of the content of educational programs implemented in educational institutions of the Federal Penitentiary Service, analysis of the requirements of professional and official activities dictated by the increased level of criminal danger of persons serving sentences in conditions of deprivation of liberty, analysis of the level of professional training of staff, analysis of the expectations of the heads of penitentiary institutions regarding the professional competence of graduates of educational institutions who are then employed as correctional staff - all this has shown the need to implement a comprehensive approach so as to form cognitive, behavioral, and motivational-value components of readiness for emergency situations, the need to supplement professional competencies that reflect the discussed readiness in relation to various specialties, and the need to conduct regular training in this area, especially in senior courses. Conclusions: in order to develop readiness in correctional staff efficiently, it is advisable to pay attention not only to the formation of cognitive and activity-based components, which are mainly focused on the content of educational disciplines, but also to the motivational and value-based components; 
the formation of the readiness involves, along with the study of special disciplines, organization of psychological training of cadets, which contributes to the implementation of an integrated approach; it is appropriate to develop general professional competence in cadets that would reflect aspects of readiness to act in emergency situations regardless of the specialty obtained; it is important to update the knowledge and skills of how to act in the event of emergencies at the final stage of training.

Keywords: emergency situations; readiness for action; competence-based approach; competence; professional competencies; educational process; educational program; integrated approach.

13.00.01 - General pedagogy, history of pedagogy and education.

F or c it a t i o n: LobanovaE.S., Kirillova T.V., Smykovskii V.V. Developing the readiness of correctional officers to act in emergency situations in the context of implementation of the competence-based approach in educational process. Penitentiary Science, 2021, vol. 15, no. 2 (54), pp. 451-460. DOI 10.46741/2686-9764-2021-15-2-451-460.

\section{Introduction}

Correctional staff perform their professional duties in conditions of increased danger, uncertainty and risks; thus, one of the main requirements to the level of their professional training includes readiness to organize actions in emergency situations. Over the past few years, there were many emergencies in correctional facilities; the majority of such situations include group incidents and mass illegal actions of inmates and persons in custody.

Emergencies in the penal system include group disobedience, mass riots, hostagetaking, escapes, and armed attacks on institutions. At the same time, situations of group disobedience that are conditionally passive, expressed in a group hunger-strike, refusal to leave the premises or go to work, a group act of self-harm that has a demonstrative blackmail meaning in order to achieve relaxation of regime requirements, etc., can develop into openly destructive actions that have a high degree of danger to the life and health of its participants. Group disobedience can escalate into mass riots and be accompanied by fires, pogroms, fights, violence against the unwanted, and taking hostages. An example of the transition of group disobedience into mass riots can be found the events that occurred in April 2020 in the Penal Colony-15 (IK-15) (city of Angarsk) of the Directorate General of FSIN Russia in the Irkutsk Oblast. Such events are characterized as stressful and going beyond the norms and established rules, which requires that staff assess the situation promptly, evaluate it and predict further events, make decisions, perform algorithms of actions under regulatory legal acts to prevent emergencies, ensure personal safety taking into account the specific situation, organize interaction not only with correctional staff, but also with other interacting bodies, demon- strate the skills of self-control and mobilization of their resources to perform official tasks in the changed conditions, etc.

Scientists define readiness to act in emergency situations as a complex phenomenon that does not have a single interpretation. Thus, the concept of readiness is regarded as the abilities and properties of an individual [7], as a state before performing a specific activity or under the influence of a factor [9], as a complex psychological formation of mental processes, emotional components, behavior motives [13], as a state formed on the basis of acquired knowledge, experience, qualities, and also including psychological components, which should comprise motives, attitudes, strategies of coping behavior, etc. [19].

D.V. Egorenkov identifies three components in the structure of readiness to overcome extreme situations: motivational and value-based, cognitive, and activity-based, each of which is implemented through its corresponding function [3]. In this case, the motivational and valuebased component includes a set of motives, attitudes, priorities, and values that determine the attitude toward the need to act in emergency conditions. The cognitive component consists of a system of knowledge on the analysis of extreme situations, designing and choosing actions in these conditions, subjective ideas about the performance of tasks based on one's own or someone else's experience in emergency situations. The activity-based component manifests itself in the skills and abilities to implement professional tasks that are implemented in simulated and real emergency situations, when making decisions, organizing individual and joint actions as part of functional groups, and interacting with other participants in the situation.

Readiness to act in emergency circumstanc- 
es is considered as one of the competencies of correctional staff; it is reflected in the educational programs of educational institutions of the Federal Penitentiary Service of Russia (FSIN Russia). Its aspects are formed within the framework of individual academic disciplines of a given specialty. However, we should pay attention to the fact that the list of these disciplines (hence, the volume and content of the formed knowledge) is not equal for different specialties. For example, in the curricula for the specialty 40.05.02 "Law enforcement", professional competence, reflecting the readiness of employees to act in emergency situations, is formed when studying such disciplines as "Activities of correctional institutions in emergency situations", "Organizing security", "Organizing convoying", "Providing security", "Psychological preparation for actions in emergency situations", "Special professional training". While for the specialty 37.05.02 "Psychology of professional activity" such professional competencies are reflected in the disciplines "Psychology of crowds and mass riots", "Psychology of safe behavior", "Psychology of communication and negotiations". A single discipline in this direction is "Tactical and special training", as well as drills. This fact may be reflected in the future when performing the tasks of official activity in emergency situations in institutions of the penal system. On the one hand, special knowledge is taken into account when assigning certain roles, for example, a psychologist is necessarily included in the negotiating team. However, due to objective situational circumstances, an officer can be included in almost any functional group, regardless of their obtained specialty.

The formation of competencies in the framework of academic disciplines is traditionally implemented through the elements of knowledge and skills. Therefore, we can say that educational process focuses on the development of the cognitive component, certain aspects of the activity component are also formed, but the tasks aimed at the formation of the motivational and value-based component of readiness to act in emergency situations are not fully implemented. It is the cognitive and activity-based components that are assessed and evaluated in the educational process, since here it is possible to determine more specific parameters and features that are evaluated in accordance with the measured scale.

In general, the term "readiness" in the formulations of professional competencies is defined as a set of knowledge of techniques, rules for organizing actions, and skills for their implementation; i.e., "prepared" means "equipped with a set of necessary knowledge and skills". This approach does not include the personal component of professional competence, which may affect the quality of performance of work tasks.

All that we have mentioned above brings to the fore the tasks of analyzing the existing conditions for the formation of components of the readiness correctional staff to act in emergency situations in the educational process, as well as finding optimal and effective means and ways to develop their personal professional competence in this field of professional activity within the framework of the competence-based approach.

\section{Methods}

The following methods were used to implement the research tasks. In order to study the notion of readiness for action in emergency situations and the current state of the competence-based approach in education, we used theoretical analysis of the problem. We also used the analysis of statistical data reflecting features of persons held in correctional institutions of the Federal Penitentiary Service of Russia, the number of crimes and emergencies, in particular group disobediences and mass riots, in penitentiary institutions over the past five years. When determining the content of professional competencies that reflect the readiness to act in emergency situations, we used the analysis of documents (educational programs, curricula, programs of disciplines implemented in educational organizations of the Federal Penitentiary Service of Russia). The results of the ascertaining experiment were used to specify the content of the competencies of correctional staff necessary for the implementation of tasks for the suppression and elimination of emergency situations in institutions and bodies of the penal system, taking into account the category of officials. In addition, we used a survey of the heads of the Federal Penitentiary Service institutions aimed at identifying their expectations and suggestions regarding the preparation of cadets for actions in emergency situations.

\section{Analysis and discussion of the results}

Emergency situations at the facilities of the penal system, which include group disobedience, mass riots, hostage-taking by inmates, escapes, and armed attacks on institutions are criminal phenomena of increased public dan- 
ger. They are characterized by openness and demonstrativeness of actions, physical and psychological violence, material harm inflicted in order to put pressure on the administration and representatives of the authorities; they pose an actual threat to the security of society, correctional staff, and persons sentenced to imprisonment; they lead to unpredictable criminal implications, disorganization of the activities of penal institutions; dealing with such implications requires huge expenditures of human and material resources. This is evidenced by the mass riots that occurred in Kirovgrad Juvenile Correctional Facility of the Directorate General of FSIN Russia for the Sverdlovsk Oblast, Penal Colony-5 of the Directorate of FSIN Russia for Saint Petersburg and the Leningrad Oblast, Zhigulevsk Juvenile Correctional Facility of the Directorate General of FSIN Russia for the Samara Oblast.

Despite the decrease in the total number of persons sentenced to imprisonment, we can note an annual deterioration in their criminogenic characteristics. According to the data published on the official website of the Federal Penitentiary Service of Russia, over the past six years, such indicators as the crime rate per 1,000 inmates have been growing: from 1.59 in 2015 to 2.59 in 2020. Despite the decrease in the number of convicted persons from 671,649 in 2015 to 482,888 in 2020 , the number of prison crimesis growing (from 838 in 2015 to 1,011 in 2020). The change in the number of crimes under Article 321 Part 3 of the RF Criminal Code (actions that disrupt the operation of the cor- rectional institution) does not have a clear trend (in 2015 - 13, in 2016 - 8, in 2017 - 6, in 2018 13 , in 2019 - 17, in 2020 - 13).

The majority of inmates are criminally infected persons who are often socially and psychologically disadvantaged. There is a constant risk of dangerous situations arising on their initiative, regardless of the conditions of serving sentences.

According to the statistical analysis of offenses and crimes in penitentiary institutions of various countries assault on staff is one of the most dangerous crimes. At the same time, the lowest value of the indicator was recorded in Russia (0.5\%), the highest - in France (24.61\%). Staff safety concerns are common in countries such as France, Latvia, Spain and the United Kingdom. Dangerous crimes include escaping from custody or while being escorted. Thus, in Norway, the share of escapes is $1.05 \%$ in the total number of offenses and crimes, in the U.S. $-0.585 \%$, in Latvia $-0.027 \%$, in the UK -0.013 , in Russia -0.004 . Low values of these indicators can be interpreted as evidence of professionalism in the actions of correctional staff in an emergency situation [4, pp. 20-21].

According to the department of security and convoying of the Federal Penitentiary Service of Russia, the number of escapes of convicts and persons in custody from the protection of temporary guards in medical organizations of the state and municipal healthcare systems in 2016-2020 was two cases. Information on emergency statistics in the penal system over the past five years is shown below.

Table Information on the number of cases of mass riots and group disobedience of convicted persons and persons held in custody in penal institutions

\begin{tabular}{|l|c|c|c|c|c|}
\hline \multicolumn{1}{|c|}{ Emergency situations } & $\mathbf{2 0 1 6}$ & $\mathbf{2 0 1 7}$ & $\mathbf{2 0 1 8}$ & $\mathbf{2 0 1 9}$ & $\mathbf{2 0 2 0}$ \\
\hline Mass riots & 2 & 2 & 3 & 2 & 1 \\
\hline Group disobedience & 20 & 13 & 21 & 20 & 12 \\
\hline Total & 22 & 15 & 24 & 22 & 13 \\
\hline
\end{tabular}

Despite the relatively low values of these crimes and the reduction in the number of emergencies in the institutions of FSIN Russia, they still happen. Consequently, the need to develop effective operational actions in correctional staff in crisis situations remains relevant.

Speaking about readiness, we find it important to focusn ot only on the need to engage promptly in a situation so as to resolve it, but also on the importance of maintaining physical and mental efficiency for a long time
$[16,20]$, since emergency circumstances can last quite a long time. For example, in foreign practice, there are cases of two-and four-day riots in US penitentiary institutions, which claimed the lives of 33 and 43 people, respectively. In the modern history of Russia, we can highlight a case of mass disobedience in Penal Colony 2 (IK-2) Salavat of the Directorate General of FSIN Russia in the Republic of Bashkortostan, where the forces and means of several territorial bodies of FSIN 
Russia were engaged in stabilizing the situation for more than a month.

Thus, the need to develop readiness to act in emergencies in correctional staff remains a relevant and necessary condition for the successful performance of professional activities. At the same time, issues concerning the possibilities of forming readiness to actin emergencies and improving the effectiveness of the results of its formation become relevant in the conditions of modern requirements of educational process. To this end, it is advisable to analyze educational programs, mainly their part concerning the tasks aimed at the formation of the type of readiness under consideration, curricula, the content of the programs of disciplines and the conditions of educational process in the perspective of the requirements of competencebased approach.

Competence-based approach in education currently implemented meets modern international requirements and is aimed at achieving results that are expressed in personal development, professionalization, and self-realization. The problem of studying competence-based approach in pedagogy is reflected in the works of I.A. Zimnyaya, A.V. Khutorskoi, L.M. Mitina, A.K. Markova, and others. The ideas of competence-based approach in the framework of higher education were studied by V.I. Baydenko, V.D. Shadrikov, S.V. Shmeleva, and others.

I.A. Zimnaya considers the concept of "competence" as a set of personal, motivational and value-based and cognitive components [5]. A.V. Khutorskoi defines competence as "a necessary set of interrelated personality qualities (knowledge, skills, methods of activity, value systems and relationships), which provides its potential ability to productively address a certain class of tasks" [15].

Competence is considered not just as a set of skills or a system of knowledge implemented in a particular field of activity. Most often, scientists emphasize the importance of the personal component of competence. Thus, V.I. Nazarov and G.A. Zasobina distinguish personal and professional competence as a complex characteristic of the developing personality of a specialist, which ensures high results of their professional activity, as well as self-development and selfdetermination in the profession [12].

L.V. Kuklina emphasizes that competencebased approach in education assumes its priority orientation toward the goals and the final result, i.e. toward a competent specialist who has all the necessary components, able to make decisions in situations of professional activity that have a high degree of uncertainty [8].

We should note that the formation of the personal component of professional competence, in contrast to the cognitive component, is given less attention in the educational process. Thus, the composition of the professional competencies under consideration is traditionally defined as a list of necessary knowledge, skills and abilities, since they primarily reflect the content of science and practice and are controlled in educational process.

There emerge certain difficulties in the process of forming and evaluating the development of the personal component. The formation of personal characteristics is usually considered as a task of psychological training, and it is really difficult to create a pedagogical tool that measures the level of personality formation as a component of professional competence. Even the assessment of the formation of the cognitive component does not give an accurate picture of the competence being tested, since it is evaluated in the educational, rather than the real practical situation of professional activity. These points are relevant for most of the professional competencies that are being formed, but they become even more pronounced in relation to the development of the readiness to act in emergencies.

A.A. Gerasimov considers the training of correctional staff to act in emergency situations as "a systematic process aimed at forming the necessary competencies and professionally important personal qualities that contribute to the implementation of competent and effective actions in emergency situations. He emphasizes that the greatest amount of training of correctional officers to act in emergency situations is carried out in the course of training at the place of service, and about a third of this amount is carried out during the implementation of programs of higher and additional professional training in educational institutions of FSIN Russia.

In the published results of empirical studies in 2017 and 2019, aimed at studying the opinion of correctional officers on the quality of preparation for actions in emergencies, the following points are of interest in the framework of the topic under discussion. Thus, $43 \%$ of respondents indicated "the need to review the content of education plans for the training of correctional office ersso as to increase the number of classes in legal and psychological training", about $70 \%$ of respondents emphasize 
"the need to organize comprehensive training of staff to act in emergency situations both in educational organizations of the Federal Penitentiary Service of Russia, and in the course of service training" [2, p. 87].

Components of readiness to act in emergency situations are usually formed with the help of practical training [17, pp. 64-73], the methods of which allow students to create a clear idea of the algorithm of actions in emergencies, aimed at solving specific tasks, and form practical skills [18]. Practical work in this case consists in the performance of functional duties by students in joint detachments for a long time and in conditions that are as close to reality as possible [6]. Practical training and exercises are complex exercises to consolidate theoretical knowledge and look like a system of training situations that may arise in emergency situations [11].

In the implementation of the competencebased approach, it is important to develop cognitive abilities in terms of the ability to analyze information promptly, determine the main, secondary and missing components in the information flow, establish cause-and-effect relationships, make a forecast of the development of the situation, make informed decisions taking into account the available resources and the specifics of the situation in conditions of a lack of information about the real situation. For this purpose, the most effective methods are active and problem-based learning. So for the development of cadets' operational thinking and the formation of practical actions in emergency situations, V.V. Manyshev and A.A. Bragin suggest using business games, since they help to engage in the activity aimed at finding a solution to a problem situation. The authors note that "methods and ways to create problematic situations include encouraging cadets to explain the conditions of the current operational situation, directly assess the situation itself and resolve contradictions between possible ways to perform the task". Depending on the complexity, business games involve analyzing the operational situation, making calculations and choosing a solution within a specific case; performing certain official duties of the operational staff members in the process of role playing; the ability to prepare oneself psychologically for solving problems that arise in a real situation; in general, the game provides visibility of the decisions made and their consequences when simulating the operational situation [10, pp. 23-24]. An example of a business game in the framework of preparing correctional staff to act in emergency situations is the game "Escape from prison or from custody" developed and implemented by the staff of Samara Law Institute of FSIN Russia [1].

In educational process, it is impossible to fully recreate a potentially dangerous and realistic emergency situation with all the details and features of the professional environment; as a result, students do not show natural psychological reactions in response to a situation of threat, they do not have a real need to make decisions and act in a situation of risks and uncertainty. Therefore, students cannot realize their own real resources and limitations for carrying out activities in non-standard critical circumstances. The main directions in the preparation of FSIN officers to act in emergency situations are the need for training to create conditions close to emergency situations and "deep actualization of the social significance of the tasks being addressed in extreme conditions of performance of official duties" [14]. At the same time, the question arises of how to implement this in practice, since it is possible to model a part of the subject, information and psychological situation. It is worth noting that the situation of expert assessment of students' actions by the teacher will be more likely to act as a factor that causes psychological stress in simulated situations, than the stress associated with the threat of danger to life and health, since there is no real danger in the educational situation.

In order to determine the actual tasks for improving the process of training future correctional staff it is advisable to analyze the existing problems and shortcomings that correctional staff and graduates of educational institutions show in their activities to prevent and combat emergencies. To this end, V.V. Smykovskii conducted an empirical study, the results of which were published in many scientific publications. The analysis of the results of the study, as well as the experience of practical work, allowed us to identify some of the problems he identified at the level of competence of staff of different positions and functional categories. Conventionally, we have designated them as follows.

The competence of management bodies includes a set of knowledge, practical experience and personal qualities of managers who are part of the management body of FSIN Russia, which allow them to address the tasks of coordination and control to stabilize the operational situation in the institution or to prevent and eliminate emergency situations. This com- 
petence involves developed analytical thinking, predictive abilities, the ability to make a choice from alternative options with an assessment of each of them, the ability to make a decision, clearly formulate it and bring it to the heads of functional groups, monitor its implementation, plan tactics and strategy of actions taking into account incoming information and the assessment of available resources, etc.

The competence of the middle commanding staff corresponds to the duties of the head of a functional group formed in emergency situations. This role involves the management of temporarily subordinate performers to implement tasks assigned by the management body to stabilize the operational situation in the insti- tution of FSIN Russia or to prevent and eliminate emergency situations.

The competence of the executor implies the presence of knowledge, skills, practical experience, and psychological characteristics of an employee who is part of a particular functional group formed in accordance with the nature of the tasks performed to stabilize the operational situation in the institution of FSIN Russia or to prevent and eliminate emergency situations.

These three competencies were formulated on the basis of empirical research and show their relationship in the process of suppressing and eliminating emergency situations in penal institutions, which can be shown in the form of the following diagram (Fig. 1).

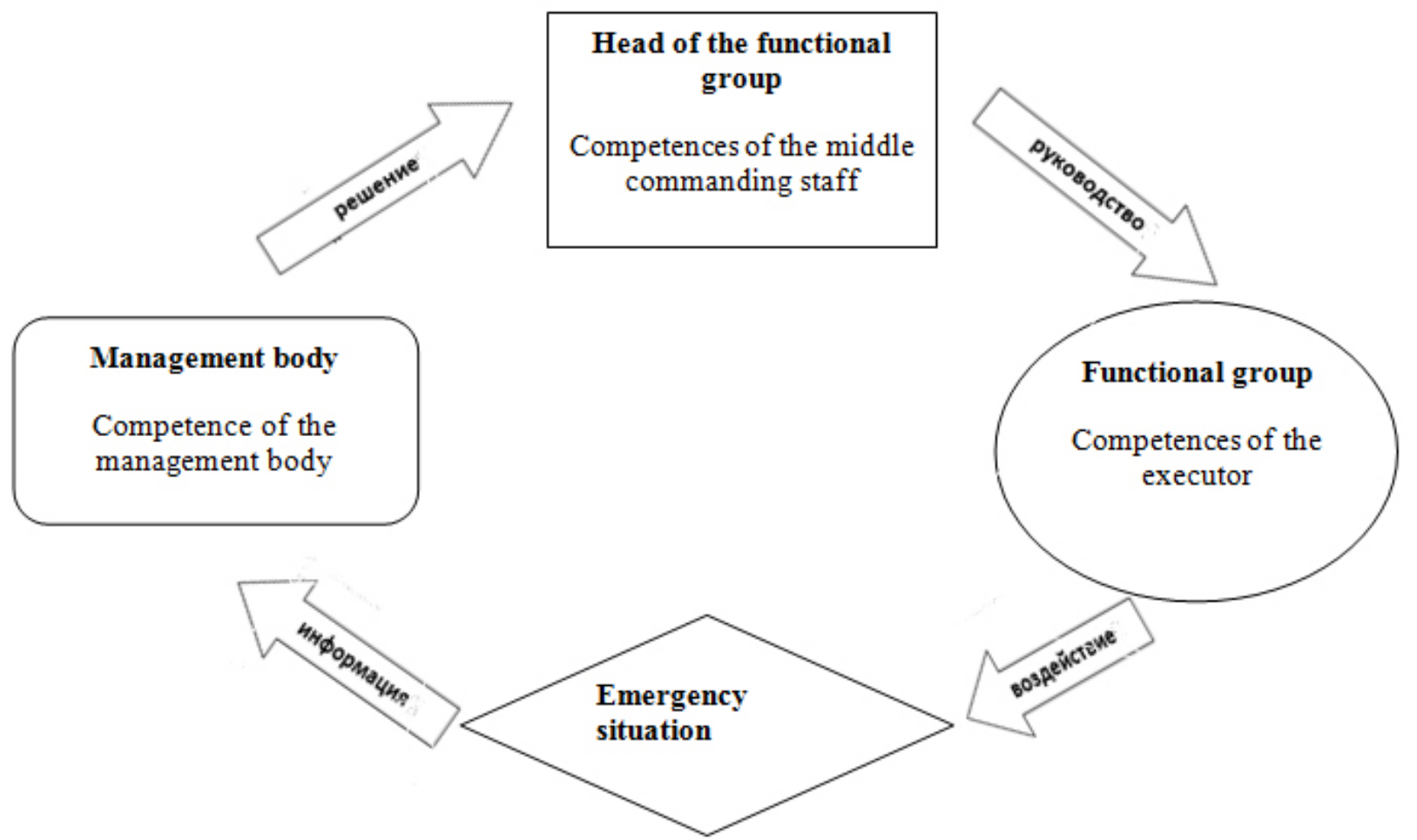

Figure. The scheme of interaction of the competencies of correctional staff in the suppression and elimination of emergencies through their carriers

In the course of training of cadets in educational institutions of FSIN Russia, tasks are mostly implemented to form the competencies of executors and middle commanding staff. In this connection, the programs of the disciplines include tasks on the formation of knowledge of the tactical and technical characteristics and the order of use of weapons and special means by the units of the penal system; tactics of actions of service units and elements of the operational group when performing tasks in emergency situations and when conducting a special operation; the main provisions on the organization and conduct of special operations at the facilities of FSIN Russia; the ability to perform operational and service-combat tasks in any conditions of the situation individually and as part of a unit; to assess the operational situation, to make appropriate decisions when acting as heads of groups of the order of battle in the conduct of special operations, to set tasks to subordinates competently; to organize and direct the activities of service detachments and elements of the operational group when per- 
forming tasks in emergency circumstances and during special operations; management skills in emergency situations, etc.

In the educational programs implemented in the educational institutions of FSIN Russia, the aspects of readiness for action in the event of emergencies are reflected in the framework of professional competencies, taking into account the content of professional activities of future specialists. For example, in the educational program of higher education in the specialty 40.05.02 "Law enforcement" (departmental specialization: organization of the regime in the penal system), this competence is defined as "the ability to perform professional tasks in special conditions, emergency circumstances, emergency situations, under the conditions of the state of emergency and in wartime, to provide first aid, to ensure personal safety and the safety of citizens in the process of addressing official tasks" (PC-23). In the educational program of higher education in the specialty 37.05.02 "Psychology of service activity", the aspects of the discussed readiness are reflected in PC-16: "the ability to effectively interact with law enforcement officers, military specialists on the organization of psychological support for operational and service activities, including in the conditions of terrorist acts, mass riots, emergencies, natural disasters, catastrophes and combat activities".

Perhaps this fact is the reason why graduates of departmental universities often experience difficulties during tactical and special training in the course of service training in penitentiary institutions, when performing duties as part of other functional groups. Another reason for these difficulties may be the fact that the main (common for different specialties) discipline focused on the formation of the competence under discussion is tactical and special training, the study of which, according to the curriculum, usually takes place in the second year of studying. It turns out that when entering the service, graduates show the so-called residual knowledge more than three years after mastering the required knowledge. In addition, for the final courses, the educational process focuses on the disciplines of specialization, and the cadets themselves focus on improving the competencies that reflect the content of the profession directly received, rather than their service activity.

Upon arrival at the institution, graduates are appointed to the positions of the middle commanding staff, inspectors of the departments of the regime, security, etc., and they are charged with conducting classes with the staff on service training and instructor-and-methodological classes. Therefore, in the educational process, it is important to pay attention to the formation of competencies that reflect the skills of methodological and pedagogical activities in the field of knowledge on tactical and special training. A separate area of training for future correctional staff concerns the formation of managerial skills necessary for the management of functional groups organized in the event of emergencies in penal institutions.

According to the opinion of the heads of a number of institutions, it is possible to form some elements of cadets' readiness to act in emergencies by implementing the following points:

- maximize the implementation of practiceoriented training in the above-listed disciplines;

- widely use simulation of the operational situation in the event of an emergency;

- engage practitioners from institutions from territorial bodies, where the preparation for actions in emergencies is at a high level, in the educational process as lecturers;

- make additions to internship programs for cadets of senior courses, supplementing them with participation in tactical and drill exercises held in the institution, as well as the possibility of conducting trial instructional classes with the personnel of the institutions;

- conduct three-day training camps for graduates of educational institutions in the territorial bodies of FSIN Russia, aimed at improving the elements of readiness for action in the case of emergency situations.

One of the topical issues of modern education in the context of the pandemic is the reduction in the ability to implement practice-oriented learning in the implementation of distance learning, during which the emphasis is placed on the study of theory. This fact can naturally have a negative impact on the level of formation of readiness for action in an emergency. Of course, the period of the pandemic and the situation on the planet in general can be described as force majeure, but the problem of forming readiness for action in the event of emergency circumstances is much broader. In the course of training in departmental educational organizations, it is possible to form only part of the competencies that reflect the readiness to act in emergency situations. This happens because there are not many classes of this kind in 
the framework of specialty disciplines; it is also due to the fact that it is difficult for students to master the relevant material.

\section{Conclusion}

The formation of the readiness of correctional staff to act in emergency situations is an urgent and relevant task, which is implemented in the educational process of educational institutions of FSIN Russia and further in the framework of on-location training of staff of penal institutions. The competence-based approach implemented in educational process involves the formation of professional competencies, the content of which includes components of readiness for action in emergency circumstances. The emphasis is traditionally placed on the formation of the cognitive and activitybased components of this readiness, which are formed through theoretical and practical training in special disciplines. At the same time, the formed knowledge and skills more closely reflect the tasks of the professional activity corresponding to the received specialty. This fact has both a positive and a negative meaning. On the one hand, specialized knowledge helps to differentiate the service tasks of officers and ensure their effective implementation by representatives of specific professional groups. On the other hand, the lack of additional knowledge hampers effective performance of official tasks as part of other functional groups, individually or as part of divisions.

The main task and at the same time the problem of forming readiness for action in emergency situations is to simulate the situations that are as close as possible to actual emergencies. In this regard, it is advisable to use active learning methods in the educational process, in particular business games and exercises. However, the possibility of frequent use of such methods is limited due to their large share in thematic planning, as well as the requirements of material and technical support (we mean the availability of additional specialized premises and spaces, the need to travel to suburban training bases, etc.).

The greatest problems can be identified in the formation of the motivational and valuebased component of readiness for action in emergency situations, which are expressed in the search for optimal and effective ways of its formation, as well as monitoring and evaluating the level at which such readiness has been formed. Researchers and practitioners emphasize the importance of the organization of psychological training in the formation of readiness for action in emergency situations. Therefore, the question arises whether to include this psychological training in the content of educational disciplines or to implement it within a separate area of activity of psychological services of educational institutions. Nevertheless, the need for a comprehensive approach to the formation of readiness for action in an emergency eventis justified and relevant. This approach, which takes into account the formation of professional motives, values and professionally important qualities, along with the components of knowledge, skills and abilities, helps to implement the competence-based approach in education to the fullest extent.

The analysis that we conducted has made it possible to identify the opportunities and problems in forming the readiness of correctional staff to act in emergency situations in the educational process of educational institutions of FSIN Russia; these opportunities and problems are relevant from the point of view of implementing the competence-based approach. The identified points can become a topic for discussion and a condition for improving the educational process in the direction of forming the professional competence of penal system staff.

\section{REFERENCES}

1. Votinov A.A., Timofeeva E.A. About the application of interactive teaching technologies in the process of professional training of future officers of the penitentiary system. Vestnik Samarskogo gosudarstvennogo tekhnicheskogo universiteta. Seriya: Psikhologo-pedagogicheskie nauki=Vestnik of Samara State Technical University Psychological and Pedagogical Sciences, 2015, no. 3 (27), pp. 60-71. (In Russ.).

2. Gerasimov A.A. Topicalissues of training of correctional staff to act in emergency situations. Voprosy sovremennoi nauki i praktiki=Issues of Modern Theory and Practice, 2020, no. 2(3), pp. 86-88. (In Russ.).

3. Egorenkov D.V. Formirovanie gotovnosti starsheklassnika k preodoleniyu ekstremal'nykh situatsii: avtoreferat dissertatsii na soiskanie uchenoi stepeni kandidata pedagogicheskikh nauk [Formation of high school student's readiness to overcome emergency situations: Candidate of Sciences (Pedagogy) dissertation abstract]. Volgograd, 2013.40 p.

4. Pertli L.F. et al. Zarubezhnyi opyt profilaktiki negativnykh protsessov, proiskhodyashchikh $v$ penitentsiarnykh uchrezhdeniyakh, i soversheniya soderzhashchimisya v nikh litsami pravonarushenii $i$ prestuplenii: analiticheskii obzor [Foreign experience in the prevention of negative processes occurring in penitentiary institutions and the commission of offenses and crimes by incarcerated persons: an analytical review]. Moscow: NII FSIN Rossii, 2017.108 p.

5. Zimnyaya I.A. Key competencies - a new paradigm of education results. Vysshee obrazovanie segodnya=Higher Education Today, 2003, no. 5, pp. 34-42. (In Russ.). 
6. Kareev V.V. Special tactical classes as a form of practical training of staff of the Federal Penitentiary Service of Russia for actions during emergencies. In: Votinova A.A. (Ed.). Ugolovno-ispolnitel'naya sistema na sovremennom etape: vzaimodeistvie nauki i praktiki: materialy mezhdunarodnoi nauchno-prakticheskoi mezhvedomstvennoi konferentsii [Penal system at the present stage: the interaction of science and practice: materials of the international research-to-practice interdepartmental conference]. Samara: Samarskii yuridicheskii institut FSIN Rossii, 2016. P. 268. (In Russ.).

7. Krutetskii V.A. Osnovy pedagogicheskoi psikhologii [Fundamentals of pedagogical psychology]. Moscow: Prosveshchenie, 1972. $255 \mathrm{p}$.

8. Kuklina L.V., Koryagina I.I. Features of the formation of key competencies in students with different professional orientation. Vestnik Cherepovetskogo gosudarstvennogo universiteta=Bulletin of Cherepovets State University, 2020, no. 4 (97), pp. 234-243. (In Russ.).

9. Levitov N.D. Psikhologiya kharaktera [Psychology of character]. Third edition, revised and supplemented. Moscow: Prosveshchenie, 1969. 424 p.

10. Manyshev V.V., Bragin A.A. Business game as one of the ways to implement problem-based learning in the training situational center of operational management. Problemy pravookhranitel'noi deyatel'nosti=Problems of Law Enforcement Activity, 2014, no. 2, pp. 22-25. (In Russ.)

11. Machekhin M.S. Massovye besporyadki igruppovye nepovinoveniya, sovershaemye vispravitel'nykh uchrezhdeniyakh: kharakteristika, prichiny i mery protivodeistviya: monografiya [Mass riots and group disobedience committed in correctional institutions: characteristics, causes and measures of counteraction: a monograph]. Perm: Permskii institut FSIN Rossii, 2020. $105 \mathrm{p}$.

12. Nazarov V.I., Zasobina G.A. Stanovlenie lichnostno-professional'noi kompetentnosti budushchikh spetsialistov $v$ usloviyakh zaochnogo obucheniya [Formation of personal and professional competence of future specialists in the conditions of distance learning]. Ivanovo: Ivanovskii gosudarstvennyi universitet, 2010. 216 p.

13. Rudik P.A.Psikhologiya [Psychology]. Moscow: Fizkul'tura i sport, 1976. 239 p.

14. Khomyakov O.V. Training of staff of special divisions of FSIN Russia on escorting to act in emergency situations. In: Penitentsiarnaya sistemaiobshchestvo: opytvzaimodeistviya: sbornikmaterialovVMezhdunarodnoinauchno-prakticheskoi konferentsii [Penal system and society: experience of interaction: collection of materials of the 5th international researchto-practice conference]. Perm: Permskii institut FSIN Rossii, 2018. Pp. 356-358. (In Russ.).

15. Khutorskoi A.V. Key competencies as a component of the personality-oriented paradigm of education. Narodnoe obrazovanie=Public Education, 2003, no. 2, pp. 59-64. (In Russ.).

16. Baldi K.A. An overview of physical fitness of female cadets at the military academies. Military Medicine, 1991, no. 10, pp. 537-539.

17. Coyle D., Hood P., Marsh D. CLIL: Content and Language Integrated Learning. Cambridge, UK: Cambridge University Press, $2010.184 \mathrm{p}$.

18. Graevenitz G. G.-W. Ausbildung des americanischen Offizers. Beispiel: US Air Force Academy. Truppenpraxis, 1988, no. 1, pp. 72-75. (In Russ.).

19. SmykovskyV., Lobanova E., Kiselev A. Opportunities of readiness formation of the criminal-executive system employees to actions in the emergency circumstances. In: Proceedings of the II International Scientific-Practical Conference "Psychology of Extreme Professions" (ISPCPEP 2019). Available at: https://www.atlantis-press.com/proceedings/ ispcpep-19/125909644 (accessed February 26, 2019).

20. Thomas Y. Woman's sports and fitness programs of the US Air Force Academy. Physician and Sportsmedicine, 1979, no. 7 , pp. 59-68.

\section{INFORMATION ABOUT THE AUTHORS}

ELENA S. LOBANOVA - Candidate of Sciences (Pedagogy), Associate Professor, associate professor at the Department of Legal Psychology and Pedagogy of the Psychological Faculty of Vologda Institute of Law and Economics of FSIN Russia, Vologda, Russian Federation. ORCID: https://orcid.org/0000-0002-8957-7417, e-mail: alenushka-248@yandex.ru

TAT'YANA V. KIRILLOVA - Doctor of Sciences (Pedagogy), Professor, Chief Researcher at the Research Center of the Research Institute of FSIN Russia, Moscow, Russian Federation. ORCID: https://orcid.org/0000-0001-8394-897X, e-mail: tatiana-kirillova@rambler.ru

VASILII V. SMYKOVSKII - Head of the Organizational and Analytical Department of the Directorate of FSIN Russia in the Arkhangelsk Oblast, Arkhangelsk, Russian Federation. ORCID: https://orcid.org/0000-0001-9503-2897, e-mail: vvs-80@ mail.ru

Received April 2, 2020 